\title{
Levantamento dos casos de anemia infecciosa equina notificados no Rio Grande do Sul pelo Laboratório Hípica no período de 2015-2017
}

Angela Barth Enastre;, Sabrina Lopes Mota, Valesca Peter dos Santos

*Autor correspondente

e-mail: angelacardosobarth@gmail.com

\section{Resumo}

A Anemia Infecciosa Equina (AIE) é uma doença viral crônica, causada por um vírus da família Retroviridae, gênero Lentivirus, que pode acometer todos os equídeos. Quanto aos sinais clínicos, caracteriza-se por picos febris, icterícia, anemia hemolítica, edema e perda de peso, principalmente em sua fase aguda. As alterações laboratoriais são anemia hemolítica, trombocitopenia, leucopenia, diminuição da resposta imunológica e aumento nos níveis de cobre e enzimas hepáticas que podem comprometer de forma irreversível o desempenho dos equídeos. Os vetores mecânicos, tabanídeos e moscas dos estábulos são responsáveis pela transmissão da enfermidade, através de sua picada. 0 teste padrão, aprovado pelo Ministério da Agricultura, Pecuária e Abastecimento (MAPA) para diagnóstico é a Imunodifusão em Ágar Gel (IDGA), de acordo com a Portaria SNDA n 84 de 19/10/1992. A Anemia Infecciosa Equina tem distribuição mundial com cerca de $70 \%$ de prevalência em animais adultos. 0 vírus possui maior prevalência em regiões úmidas e montanhosas de clima tropical e subtropical, onde há grande quantidade de vetores. 0 presente estudo teve por objetivo fazer um levantamento do número de exames de AIE realizados no período de janeiro de 2015 a janeiro de 2017 e do número de exames positivos detectados no mesmo período pelo Laboratório Hípica em Porto Alegre/RS. Os casos positivos foram caracterizados quanto ao sexo e mesorregião do estado em que se encontravam. De janeiro de 2015 a janeiro de 2017 foram realizados 85.668 ensaios de Anemia Infecciosa Equina. Deste total, foram detectados 76 exames com resultado positivo na técnica de Imunodifusão em Ágar Gel. Em 2015 foram comunicados 26 exames positivos, sendo 12 machos e 14 fêmeas, 69\% deles residentes em Porto Alegre e arredores (Porto Alegre, Canoas, Eldorado do Sul, Guaíba) - mesorregião metropolitana de Porto Alegre. Em 2016, foram comunicados 50 animais positivos, sendo 32 machos e 18 fêmeas, 42\% destes pertencentes a mesorregião metropolitana de Porto Alegre. Em janeiro de 2017 não foram diagnosticados animais positivos. Conforme dados publicados no Informativo Técnico $\mathrm{n}^{\circ} 5 / \mathrm{ano}_{0} \mathrm{5}$ 
em maio de 2014 pelo Departamento de Defesa Agropecuária (DDA) - Secretaria da Agricultura Pecuária e Irrigação do estado do Rio Grande do Sul, a maior população de equinos encontra-se na mesorregião sudoeste e sudeste do estado. Embora a incidência de AIE no estado do RS seja considerada baixa, fato que justificou o aumento do prazo de validade dos exames para 180 dias a partir de 20 de setembro de 2014, o que se verifica é que nas regiões onde a fiscalização oficial é mais intensiva é onde se detectam animais positivos. De acordo com dados publicados em 2014 pela própria DDA - SEAPI/RS, o número de Guias de Trânsito Animal (GTA), o número de exames realizados e, consequentemente, o número de focos positivos aumenta de forma diretamente proporcional à intensidade de fiscalização, pois impõem o acesso diagnóstico a faixas da população que não realizavam exames sanitários como rotina. Os resultados obtidos revelam que a doença, apesar de controlada nos grupos de animais que circulam nos principais eventos equestres, persiste em focos localizados em regiões e comunidades que permanecem à margem de controle sanitário.

Palavras-chave: Anemia infecciosa. Equídeos. Diagnóstico. 